\title{
Complex reconstruction of the lower extremity following sarcoma resection: a literature review
}

\author{
Beina Azadgoli, Antoine L. Carre, David P. Perrault, Alex K. Wong \\ Division of Plastic and Reconstructive Surgery, Department of Surgery, Keck School of Medicine of USC, Los Angeles, CA 90033, USA.
}

Correspondence to: Dr. Alex K. Wong, Division of Plastic and Reconstructive Surgery, Department of Surgery, Keck School of Medicine of USC, 1510 San Pablo Street, Los Angeles, CA 90033, USA. E-mail: Alex.Wong@med.usc.edu

How to cite this article: Azadgoli B, Carre AL, Perrault DP, Wong AK. Complex reconstruction of the lower extremity following sarcoma resection: a literature review. Plast Aesthet Res 2018;5:3. http://dx.doi.org/10.20517/2347-9264.2017.32

Received: 29 Apr 2017 First Decision: 30 Nov 2017 Revised: 3 Jan 2018 Accepted: 4 Jan 2018 Published: 29 Jan 2018

Science Editor: Raúl González-García Copy Editor: Jun-Yao Li Production Editor: Huan-Liang Wu

\begin{abstract}
While amputation was traditionally the only option available for patients with sarcomas of the extremities, chemotherapy, radiation, and advances in microsurgical technique have allowed many patients to undergo limb-salvaging procedures. Given the low incidence and heterogeneity of these tumors, there is currently no standard treatment algorithm for limb reconstruction after large sarcoma resection. Thus, we systematically reviewed the various types of free tissue transfer used for the reconstruction of lower limbs after sarcoma resection. Techniques were described based on anatomic location. This literature review supports free tissue transfer as a safe and acceptable modality for reconstruction after sarcoma resection of the lower limb. It allows for the application of healthy vascularized tissue to the defect while also providing freedom of flap positioning. Flap choice is dependent on tumor and defect size, tissue type and function, as well as donor site availability.
\end{abstract}

Keywords: Lower extremity, sarcoma, reconstruction

\section{INTRODUCTION}

Soft tissue and bone sarcomas represent about $1 \%$ of all adult tumors ${ }^{[1]}$, affecting 1.8-5 out of every 100,000 people annually ${ }^{[2]}$. The lower limb is the most common site of sarcoma occurrence, representing $29 \%-40 \%$ of all cases ${ }^{[3,4]}$. Although amputation was traditionally the only option available for patients with sarcoma of the extremities, recent implementation of a multimodal treatment approach along with advancements in chemotherapy and microsurgical techniques has led to the influx of limb salvage therapy for these cancers $^{[5,6]}$. Currently, wide tumor excision combined with adjuvant and or neo-adjuvant therapy is the standard of care for the successful treatment of sarcoma of the lower limbs ${ }^{[2]}$.

\footnotetext{
(c) (1)

(C) The Author(s) 2018. Open Access This article is licensed under a Creative Commons Attribution 4.0 International License (https://creativecommons.org/licenses/by/4.0/), which permits unrestricted use, sharing, adaptation, distribution and reproduction in any medium or format, for any purpose, even commercially, as long as you give appropriate credit to the original author(s) and the source, provide a link to the Creative Commons license, and indicate if changes were made.
}

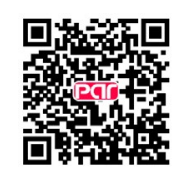


Quite often, sarcoma excision results in large anatomical soft tissue deficits with resultant exposure of vital structures such as bones, tendons, and neurovascular bundles, necessitating complex soft tissue reconstruction with vascularized soft tissue transfer thus facilitating further treatments as well as maintaining or regaining structural function and integrity of the limb in question. To this end both pedicled and free tissue transfers have become a central component of lower extremity salvage after resection and chemo-radiation therapy. Recent data has shown that these complex reconstructions have provided faster recovery with adequate soft tissue reconstruction and maintenance of functionality of the limb ${ }^{[2,6-11]}$.

Currently there is no standard treatment algorithm for limb reconstruction after large sarcoma resection. In part this due to the low incidence of these tumors as well as the heterogeneity of extremity sarcoma. This problem is further compounded by the multitude of neo-adjuvant modalities that are used to treat these tumors as well as the timing of the oncological resection. Hence a comprehensive reconstructive approach that maximizes the maintenance of function and aesthetics depends primarily on the location and size of the defects as well as the muscles, tendon, blood vessels and nerves that were extirpated. The goal of this literature review is to therefore outline various author reports published in the current literature describing the various types of free tissue transfer used for the reconstruction of the lower limbs after sarcoma resection.

\section{METHODS}

The PubMed database was used to review literature describing free tissue coverage of the lower extremity following soft tissue sarcoma resection. The entire PubMed library was used dating to 2016. The following search terms were used: "Neoplasms, Connective and Soft Tissue" [Mesh] OR ("sarcoma" [MeSH Terms] OR "sarcoma" [All Fields]) AND ("lower extremity" [MeSH Terms] OR ("lower" [All Fields] AND "extremity"[All Fields]) OR "lower extremity" [All Fields]) AND ("free tissue flaps" [MeSH Terms] OR ("free"[All Fields] AND "tissue" [All Fields] AND "flaps" [All Fields]) OR "free tissue flaps" [All Fields]. All studies published in the English language were included. Articles were excluded if they met the following criteria: exclusively pediatric patients, cadaver subjects, pathology of the pelvic girdle, exclusively pathology related to trauma, pathology related to skin neoplasms, and studies exclusively describing pedicled flaps. Table 1 lists the studies included in this review. Table 2 describes the types of flaps used for lower extremity reconstruction by region.

\section{RECONSTRUCTION BASED ON TUMOR LOCATION \\ Thigh}

Several factors must be taken into consideration when approaching reconstruction of the thigh. Primarily, malignant sarcomas of the femur are generally challenging to treat because radical resection of the tumor often requires simultaneous resection and reconstruction of the major femoral vessels. Tumor proximity to critical neurovascular structures is particularly of concern in the adductor compartment, where outcomes are generally poor, with high local recurrence rate, high complication rates and short long-term survival ${ }^{[12]}$.

The first report of reconstruction of major vessels was by Fortner et al. ${ }^{[13]}$ for the treatment of seven patients with sarcoma involving the iliac and femoral vessels. In their study, 3 out of 7 patients underwent vascular reconstruction with polyester or vein grafts, resulting in less postoperative complications and edema compared to the remaining 4 patients who did not undergo vascular reconstruction. In a series by Muramatsu et al. ${ }^{[14]}, 12$ out of 14 patients requiring arterial reconstruction underwent femoropopliteal reconstruction using a contralateral greater saphenous vein (GSV) graft ranging from 12-30 cm, while the 2 who required femoroinguinal reconstruction received expanded polytetrafluoroethylene (ePTFE). Twelve of their 15 patients additionally required venous reconstruction of the superficial vein, deep femoral vein, and greater saphenous vein, which was also done using a GSV or ePTFE graft. Of these patients, 6 had received 
Table 1. Studies included

\begin{tabular}{|c|c|c|}
\hline Author & Year & Study describes \\
\hline Abramson et al. ${ }^{[]_{1}}$ & 1997 & Free tissue transfer + radiotherapy \\
\hline Cordeiro et al..$^{[6]}$ & 1994 & Free tissue transfer + bone reconstruction \\
\hline Serletti et $a l^{[7]}$ & 1998 & Free tissue transfer \\
\hline Heiner et $a l_{.}^{[8]}$ & 1993 & Free tissue transfer \\
\hline Barner-Rasmussen et al. ${ }^{[9]}$ & 2009 & Free tissue transfer \\
\hline Leow et al. ${ }^{[10]}$ & 2005 & Free tissue transfer + bone reconstruction \\
\hline Momeni et al. ${ }^{[1]]}$ & 2011 & Free tissue transfer \\
\hline Muramatsu et al. ${ }^{[14]}$ & 2011 & Free tissue transfer \\
\hline Ng et al. ${ }^{[15]}$ & 2008 & Free tissue transfer \\
\hline Zbuchea $^{[16]}$ & 2016 & Free tissue transfer \\
\hline Nahabedian et al. ${ }^{[17]}$ & 1999 & Free tissue transfer \\
\hline Vaienti et al. ${ }^{[18]}$ & 2013 & Free tissue transfer \\
\hline Cadenelli et al. ${ }^{[19]}$ & 2015 & Free tissue transfer \\
\hline Baxter et al..$^{[20]}$ & 2007 & Free tissue transfer \\
\hline Miyamoto et al. ${ }^{[21]}$ & 2014 & Free tissue transfer \\
\hline Lee et al. ${ }^{[22]}$ & 2004 & Free tissue transfer + radiotherapy \\
\hline Choudry et al. ${ }^{[23]}$ & 2008 & Free tissue transfer \\
\hline Saito et $a]^{[24]}$ & 2010 & Free tissue transfer + bone reconstruction \\
\hline Zweifel-Schlatter et al. ${ }^{[25]}$ & 2006 & Free tissue transfer \\
\hline Hong et al. ${ }^{[26]}$ & 2005 & Free tissue transfer \\
\hline Weichman et al. ${ }^{[27]}$ & 2015 & Free tissue transfer \\
\hline Agostini and Agostini ${ }^{[28]}$ & 2009 & Free tissue transfer \\
\hline Cribb et al. ${ }^{[29]}$ & 2010 & Free tissue transfer \\
\hline Brenner and Rammelt ${ }^{[30]}$ & 2002 & Free tissue transfer \\
\hline Medina et al. ${ }^{[31]}$ & 2014 & Free tissue transfer \\
\hline Struckmann et al. ${ }^{[32]}$ & 2014 & Free tissue transfer \\
\hline Zaretski et al. ${ }^{[33]}$ & 2004 & Bone reconstruction \\
\hline Capanna et al. ${ }^{[34]}$ & 1993 & Bone reconstruction \\
\hline Beris et al..$^{[35]}$ & 2011 & Bone reconstruction \\
\hline Yajima and Tamai ${ }^{[36]}$ & 1994 & Bone reconstruction \\
\hline Duffy et al. ${ }^{[37]}$ & 2000 & Bone reconstruction \\
\hline Ruch and Koman ${ }^{[38]}$ & 1997 & Bone reconstruction \\
\hline Mastorakos et al. ${ }^{[39]}$ & 2002 & Bone reconstruction \\
\hline Enneking et al. ${ }^{[40]}$ & 1993 & Nerve reconstruction \\
\hline Doi et al..$^{[4]]}$ & 1998 & Nerve reconstruction \\
\hline Doi et al..$^{[42]}$ & 1999 & Nerve reconstruction \\
\hline Fortner et al. ${ }^{[13]}$ & 1977 & Vascular reconstruction \\
\hline Tsukushi et al. ${ }^{[43]}$ & 2008 & Vascular reconstruction \\
\hline Nishinari et al. ${ }^{[44]}$ & 2015 & Vascular reconstruction \\
\hline Wortmann et al..$^{[45]}$ & 2017 & Vascular reconstruction \\
\hline Rosenthal et al.$^{[46]}$ & 1993 & Radiotherapy \\
\hline O'Sullivan et al..$^{[47]}$ & 2004 & Radiotherapy \\
\hline Baldini et al. ${ }^{[48]}$ & 2013 & Radiotherapy \\
\hline Arbeit et al.. ${ }^{[49]}$ & 1987 & Radiotherapy \\
\hline Shiu et al. ${ }^{[50]}$ & 1984 & Radiotherapy \\
\hline O'Sullivan et al. ${ }^{[51]}$ & 2002 & Radiotherapy \\
\hline Cheng et al. ${ }^{[52]}$ & 1996 & Radiotherapy \\
\hline Kunisada et al. ${ }^{[53]}$ & 2002 & Radiotherapy \\
\hline Davis et al. ${ }^{[54]}$ & 2005 & Radiotherapy \\
\hline Townley et al. ${ }^{[55]}$ & 2013 & Radiotherapy \\
\hline Chao et al. ${ }^{[56]}$ & 2012 & Radiotherapy \\
\hline Hidalgo et al. ${ }^{[57]}$ & 1992 & Radiotherapy \\
\hline Brennan et al. ${ }^{[58]}$ & 1987 & Radiotherapy \\
\hline Ormsby et al. ${ }^{[59]}$ & 1989 & Radiotherapy \\
\hline Hidalgo and Carrasquillo[60] & 1992 & Radiotherapy \\
\hline Spierer et al. ${ }^{[61]}$ & 2003 & Radiotherapy \\
\hline Sadrian et al. ${ }^{[62]}$ & 2002 & Radiotherapy \\
\hline Pisters et al. ${ }^{[63]}$ & 1996 & Outcomes \\
\hline Popov et al.. ${ }^{[64]}$ & 2000 & Outcomes \\
\hline Penna et al. ${ }^{[65]}$ & 2011 & Outcomes \\
\hline Lopez et al. ${ }^{[2]}$ & 2015 & Outcomes \\
\hline
\end{tabular}


Table 2. Types of flaps used for lower extremity reconstruction based on region

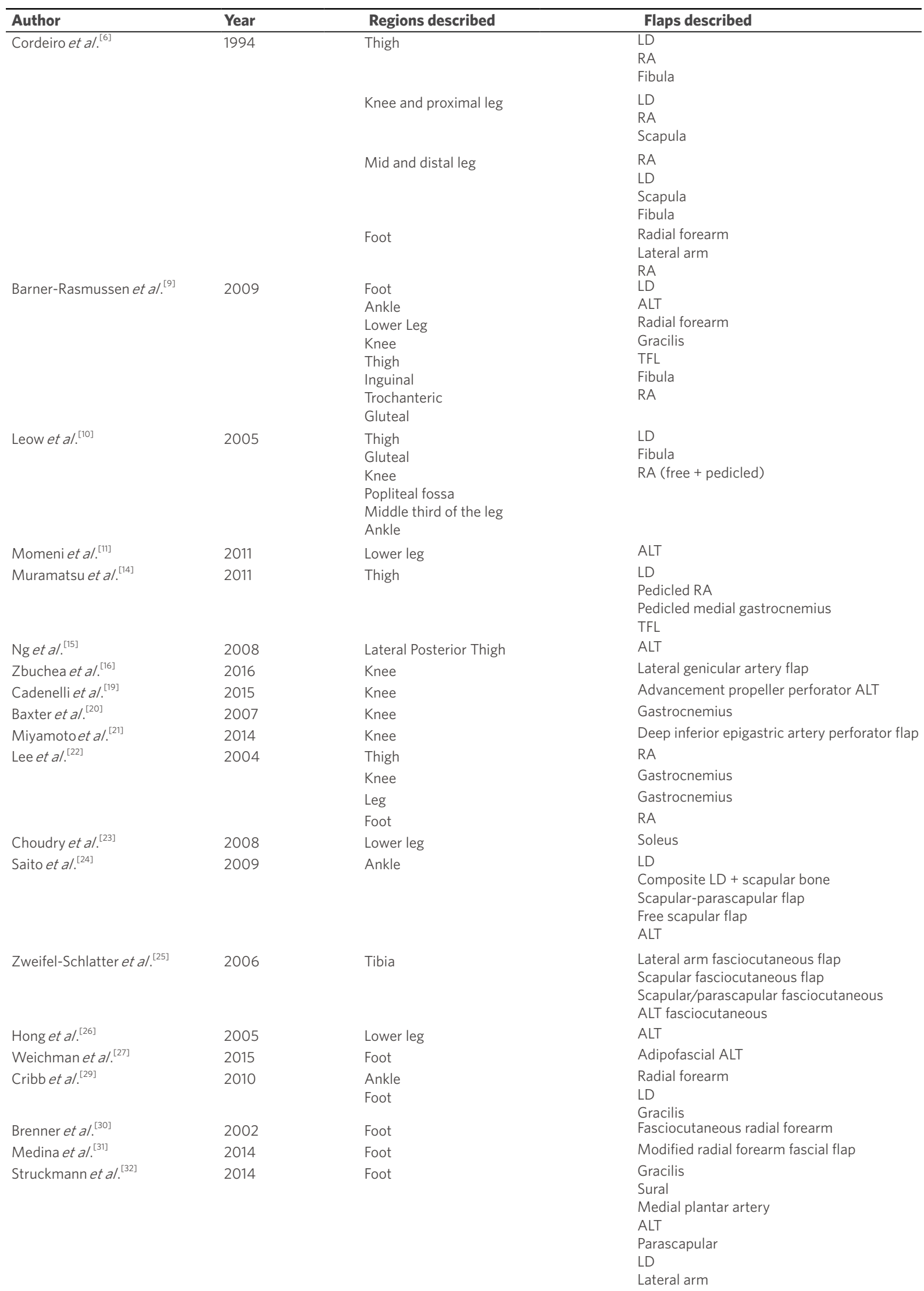




\begin{tabular}{|c|c|c|c|}
\hline Zaretski et al. ${ }^{[33]}$ & 2004 & $\begin{array}{l}\text { Femur } \\
\text { Tibia }\end{array}$ & $\begin{array}{l}\text { Free vascularized fibula flap } 4 \text { allograft } \\
\text { Free double-barreled fibula }\end{array}$ \\
\hline Capanna et al. ${ }^{[34]}$ & 1993 & $\begin{array}{l}\text { Femur } \\
\text { Tibia }\end{array}$ & Free vascularized fibula flap + allograft \\
\hline Beris et $\left.a\right|^{[35]}$ & 2011 & $\begin{array}{l}\text { Femur } \\
\text { Tibia }\end{array}$ & $\begin{array}{l}\text { Free vascularized fibula } 4 \text { allograft } \\
\text { Free double-barreled fibula }\end{array}$ \\
\hline Yajima and Tamai ${ }^{[36]}$ & 1994 & $\begin{array}{l}\text { Femur } \\
\text { Tibia } \\
\text { Ankle }\end{array}$ & Twin-barrelled vascularized fibular graft \\
\hline Duffy et $a l .{ }^{[37]}$ & 2000 & $\begin{array}{l}\text { Femur } \\
\text { Tibia }\end{array}$ & Free vascularized fibula \\
\hline Rush and Koman ${ }^{[38]}$ & 1997 & Tibia & $\begin{array}{l}\text { Fibula-flexor halluces longus osteomuscular } \\
\text { flap }\end{array}$ \\
\hline Mastorakos et al. ${ }^{[39]}$ & 2002 & Tibia & $\begin{array}{l}\text { LD } \\
\text { RA } \\
\text { Gastrocnemius-Soleus } \\
\text { Gastrocnemius-RA } \\
\text { Gracilis + motor nerve }\end{array}$ \\
\hline Doi et al. ${ }^{[42]}$ & 1999 & Thigh & $\mathrm{LD}+$ motor nerve \\
\hline & & Lower leg & Gracilis + motor nerve \\
\hline
\end{tabular}

LD: latissimus dorsi; RA: rectus abdominis; ALT: anterior lateral thigh

free latissimus dorsi flaps, while the remaining patients received pedicled flaps. In the patients who were reconstructed using free flaps, the only complications were leg edema and mild lymphedema, which the authors attributed to ischemic reperfusion or venous/lymphatic insufficiency. The use of a myocutaneous flap in combination with an autologous vein graft also results in decreased postoperative infection rates, treatment of lymphedema and fistula, and increased graft patency rates ${ }^{[14]}$.

Aesthetically, reconstruction of the thigh requires a large flap with muscle bulk that can eliminate dead space while providing adequate contour ${ }^{[10]}$. The use of a free rectus abdominis flap has been reported to be particularly successful for this purpose ${ }^{[6,10]}$. The latissimus dorsi flap, which is thin, large with a long vascular pedicle, \pm neurotization has also been used for large defects of the thigh ${ }^{[6,10]}$. The use of the anterior lateral thigh (ALT) flap for large thigh defects, particularly of the posterior thigh, has also been reported ${ }^{[15]}$.

\section{Knee}

Obtaining adequate soft tissue coverage of the knee remains challenging for many plastic surgeons, not only because of the biomechanics of the knee, but also due to exposure of vital structures as well as the joint space $^{[16-18]}$. Rotational muscle flaps or myocutaneous flaps such as gastrocnemius or reverse anterior lateral thigh flaps have been the mainstay for the reconstruction of tumors in this location. These flaps usually have low donor - site morbidity. However more complex defects may require the use of free tissue transfer. In these cases the deep-seated recipient popliteal vessels of the knee can make microvascular anastomosis difficult $^{[19]}$, an autologous vein graft loop can be used and the distal SFA and SFV can be used as recipient vessels if there is an extended field of neoadjuvant radiation ${ }^{[14]}$.

Multiple donor sites have been successful used in free flap coverage of knee defects. These include latissimus dorsi, rectus abdominis, and scapula flaps ${ }^{[6]}$. When there is a large contour defect in the popliteal fossa that does not require much filling of the muscular space, Leow et al. ${ }^{[10]}$ have also described the use of a free minitransverse rectus abdominis (TRAM) myocutaneous flap.

In many cases where complex reconstruction of the knee region is needed, salvage of the popliteal artery, which can often be involved in the disease process, becomes critical. This has traditionally been accomplished using a combination of a local gastrocnemius flap with an interpositional vein graft $^{[20]}$. However, Miyamoto et al. ${ }^{[21]}$ described two cases of successful one-stage reconstruction of complex knee defects including the popliteal artery using a free flow-through ALT flap. Although the use of a deep 
epigastric artery perforator flap has also been used for these situations, this flap is often too bulky and provides a less aesthetic option.

\section{Below knee}

In the distal leg, dead-space obliteration is generally not a concern and the use of bulky musculocutaneous flaps, such as TRAM flaps, can result in significant contour deformities. As a solution, several authors describe the ALT flap as a preferred method for distal lower extremity defects following sarcoma resection, given the easy ability to reshape the flap ${ }^{[11,22]}$. In a series by Barner-Rasmussen et al ${ }^{[9]}, 73$ patients with soft tissue tumors located predominantly in the distal leg received 75 free-flap procedures with a $95 \%$ flap survival rate and a $97 \%$ limb salvage rate. A majority of the flaps used were latissimus dorsi flaps $(72 \%)$ and ALT flaps (12\%). The rectus abdominis and latissimus dorsi flaps as well as free scapula flaps have been described for this region by Cordeiro et al. ${ }^{[6]}$ with an overall success rate close to $90 \%$. Other flaps commonly used in the lower leg are the radial forearm flap, gracilis flap, tensor fascia lata flap, and fibula flap ${ }^{[9]}$.

\section{Ankle/foot}

Several factors must be taken into account when reconstructing oncologic defects of the ankle and foot. In addition to considering the need for adjuvant radiotherapy, the soft tissue of this area is very thin and must provide a smooth surface for the tendons underneath. Traditional flaps used to cover defects of the distal third of the foot have included the rectus abdominis, latissimus dorsi, gracilis, and rectus femoris flaps ${ }^{[23]}$. Free scapular and ALT flaps have also been used with adequate results ${ }^{[24]}$. Muscle flaps provide excellent coverage, and while they are initially quite bulky for this region, they flatten significantly with time as they atrophy. Thus fasciocutaneous flaps have been described as a successful alternative with superior contouring ${ }^{[25,26]}$.

Although the versatile ALT flap has also been used in the past, the amount of adipose deposit in this flap can be addressed by primary thinning via a supra-fascial dissection or secondary procedure using mechanical lipectomy. A third approach was described by Weichman et al. ${ }^{[27]}$ where they reported a series using an adipofascial ALT flap with a split thickness skin graft to cover dorsal foot defects on three patients after sarcoma resection. In addition to its superior contour, the fascial plexus of the adipofacial flap is stronger than that of the thinned ALT, and the extra fascia can be used to reconstruct local tendons ${ }^{[28]}$.

The fasciocutaneous radial forearm flap has also been reported to have good results in reconstruction of the foot and ankle, providing normal contour and durable stability ${ }^{[29,30]}$. Unfortunately however, it can result in significant donor-site morbidity and occasional bulkiness. Thus, Medina et al. ${ }^{[31]}$ proposed a using a radial forearm fascial free flap for dorsal foot defects and reported its use in a patient with wound dehiscence following sarcoma resection and radiation therapy, with no resulting complications or contour defects. Another flap that can provide excellent results in the ankle if the size of the defect permits is the temporalis fascia free flat ${ }^{[6]}$.

In contrast to the dorsum of the foot, reconstruction of the weight-bearing sole of the foot requires strong soft tissue that is resistant to pressure, weight, and stress. Struckmann et al. ${ }^{[32]}$ covered heel defects in 12 patients with a variety of free flaps including latissimus dorsi, gracilis, lateral arm, ALT, and parascapular free flaps. They found that myofasciocutaneous flaps had the best functional results, followed by adipocutaneous and muscle flaps with split-thickness skin grafts, while fasciocutaenous flaps had the lowest outcomes. However there was no significant difference between specific flap type.

\section{ADDITIONAL CONSIDERATIONS: COMPROMISED STRUCTURES}

\section{Bone involvement}

For bone reconstruction, the flap is chosen based on specific patient needs including location of the lesion, level of activity of the individual, need for adjuvant therapy, and growth potential. The most commonly 
harvested bone flap is the free fibula flap, which can be used in three major reconstructive ways: traditional vascularized fibula flap, vascularized fibula flap combined with an allograft, and vascularized doublebarreled fibula ${ }^{[33]}$.

The traditional vascularized fibula flap as a bony replacement is indicated in areas that endure lighter loads or when reinforcement of weak areas is needed. The free fibula flap with an allograft, which was first described by Capanna et al. ${ }^{[34]}$ in 1993, involves the insertion of the vascularized fibular graft into the intramedullary canal of an allograft, which is then used to fill the bony defect. This flap provides strength and stability early on, making it ideal for anatomical locations where high forces are applied. For areas that must withstand intermediate stress loads, the free double-barreled fibula flap is typically chosen. This flap allows for twice the volume of the fibula to be substituted with the same number of microvascular anastomoses ${ }^{[33]}$. It is generally indicated for femur and proximal tibia reconstruction as well as reconstruction of the tibia of younger patients who are physically active ${ }^{[35,36]}$. Additionally for radiationinduced long-bone fractures, the vascularized fibula can also be osteotomized longitudinally and used as an onlay graft ${ }^{[37]}$. The fibula can also be harvested as a combined osteocutaneous flap for composite defects of the lower extremity ${ }^{[6,10]}$.

An additional osteomuscular flap that has been reported to have good outcomes for coverage after distal tibial osteosarcoma resection is the fibula-flexor hallucis longus osteomuscular flap ${ }^{[38]}$. Saito et al. ${ }^{[24]}$ also describe adequate aesthetic and functional outcomes with the use of a free composite graft of latissimus dorsi and scapular bone as well as a free osteocutaneous scapular-parascapular flap. Finally, in cases of allograft bone reconstruction of the lower extremities, soft tissue flap coverage using latissimis dorsi and rectus abdominis flaps has been shown to maximize limb salvage ${ }^{[39]}$.

\section{Nerve reconstruction}

Radical sarcoma resection often leads not only to extensive soft tissue defects, but also suboptimal degrees of functionality secondary to damage to surrounding nerves. Functional outcomes following conventional limb-sparing procedures reported in the literature have been close to $75 \%{ }^{[40]}$.

Reinnervated muscle transfer, which has been extremely valuable in a number of reconstructive procedures, may also become necessary in patients with sarcoma resection. Doi et al ${ }^{[41]}$ describe a patient with synovial sarcoma of the anterior compartment of the lower leg who received a gracilis flap to cover the defect. The motor nerve of the gracilis was sutured to the motor branch of the tibialis anterior muscle from the peroneal nerve, resulting in gradual increase in power and range of toe and ankle extension postoperatively. In a second series by Doi et al ${ }^{[42]}$, reinnervated latissimus dorsi transfer was used to improve or supplement knee flexion or extension by connecting to the sciatic or femoral nerve at the time of reconstruction.

\section{Vascular reconstruction}

While arterial reconstruction is always indicated after limb-sparing surgery to prevent ischemia, the need for venous reconstruction is not as well-established, as venous ligation compromise the limb. Studies showing high occlusion rates have led to debates regarding the benefits of venous revascularization ${ }^{[43]}$. Additionally, there have been reports of symptoms of severe venous insufficiency such as edema, claudication, and hyperpigmentation after reconstruction ${ }^{[44]}$.

A large series of lower limb soft tissue sarcoma resection with arterial and venous reconstruction was conducted by Nishinari et al. ${ }^{[4]}$ in 25 patients. Graft occlusion rates were found to be significantly greater in patients who received synthetic grafts vs. those who received saphenous vein grafts $(P=0.02)$, which is consistent with the results of other studies ${ }^{[14]}$. However occlusion rates were not different between arterial and venous reconstruction and there was no association between prior radiotherapy and graft occlusion ${ }^{[44]}$. Wortman et al. ${ }^{[45]}$ reported one-year patency rates of venous bypass grafts to be $65 \%$, with high numbers of 
overall bypass-related complications including thrombosis and emboli as well as infections. Common wound complications that occur are wound healing difficulties, infections, and lymphatic fistulas.

\section{NEOADJUVANT AND ADJUVANT THERAPY}

Surgery with wide margins alone can be implemented to treat sarcoma of the extremities that is subcutaneous or intramuscular, small in size, or low in grade. However, if the resected margin is close, or if there is extramuscular involvement, surgery must be combined with adjuvant radiotherapy. For those that are high-grade or large in size, neoadjuvant chemotherapy must also be considered ${ }^{[46]}$. The need for additional therapy is often a determining factor in flap selection, as wound-healing difficulties can delay the onset of adjuvant therapy and negatively affect long-term survival.

Radiotherapy may be administered either pre- or postoperatively with similar local control and overall survival rates ${ }^{[47]}$. The concern with radiation therapy is the complications it causes with wound healing. Reported complications have ranged from $33 \%-44 \%$ in the past, with severe morbidity in $22 \%-27 \%$ of patients ${ }^{[48-50]}$. Abramson et al. ${ }^{[5]}$ however only reported a $12.5 \%$ wound complication rate, including a patient who developed radiation necrosis and required a second free tissue transfer months after his initial treatment.

While preoperative radiotherapy results in higher rates of wound complications ${ }^{[51-53]}$, patients treated with postoperative radiotherapy experience more long-term fibrosis, edema and joint stiffness ${ }^{[54]}$. The National Cancer Institute of Canada (NCI Canada) conducted a randomized control trial comparing wound complications in patients who received preoperative $v s$. those postoperative radiotherapy and found that $35 \%$ of those in the preoperative group had major wound complications compared to $17 \%$ of those in the postoperative group ${ }^{[51]}$. O'Sullivan et al ${ }^{[51]}$ found higher rates of wound complications and reoperations in patients who received preoperative radiation. However a larger percentage of patients with wound complications in the postoperative radiation group required other invasive procedures.

Townley et al ${ }^{[55]}$ compared patients with preoperative irradiation to a control group who received no radiation and found similar microvascular complication rates such as those requiring intra-operative revision or flap reexploration or loss. Though wound healing complications were more common in the group who received radiation, the ultimate outcomes were similar between both groups. Some factors associated with wound complications in sarcoma patients who receive preoperative radiation are tumor size $>10 \mathrm{~cm}$, tumor proximity to skin surface $<3 \mathrm{~mm}$, and current smoking status ${ }^{[48]}$.

Chao and associates compared complication rates between patients receiving neoadjuvant and adjuvant irradiation and found no significant difference in perioperative complication rates or rates of salvaged pedicle thrombosis between the two groups. However, the rate of total free flap loss was lower in patients receiving neoadjuvant radiation, suggesting that the introduction of new, well-vascularized tissue counteracts the effects of the radiation. The authors also attributed this finding to the fact that higher doses and larger fields of irradiation are involved with adjuvant therapy, and with neoadjuvant therapy, irradiated tissue may be excised during tumor resection. Additionally, they found that late recipient-site complications (occurring $>30$ days after surgery) occurred more frequently in patients who received adjuvant radiation $(26.1 \%$ vs. $6.8 \%$, $P=0.0006)$, although the reoperation rate following these complications was similar between the group ${ }^{[56]}$. Because wound complications are generally treatable without resulting in permanent damage, preoperative radiotherapy is preferred by many practitioners ${ }^{[48]}$.

Brachytherapy, another form of adjuvant therapy, is a method of administering radioisotopes directly into a surgical wound to treat residual tumor ${ }^{[57]}$. Addition of brachytherapy to surgical excision has been shown to reduce tumor recurrence rates from $14 \%$ to $4 \%{ }^{[58]}$. Brachytherapy was initially administered during 
the immediate postoperative period and resulted in high rates of wound complications ${ }^{[49]}$. Waiting until at least the 5 th postoperative day is associated with significantly lower rates ${ }^{[59]}$. In a study by Lee et al ${ }^{[22]}$, brachytherapy was initiated about 7 days after free tissue transfer and resulted in a $29 \%$ complication rate, including partial-thickness skin necrosis, venous thrombosis necessitating flap exploration, kinking of the brachytherapy catheters, and partial flap skin loss. Hidalgo et al ${ }^{[60]}$ described 3 patients who were treated with adjuvant brachytherapy 7-10 days postoperatively with no wound-healing complications. Although considered typically safe, the number of wound complications requiring reoperation has been shown to be higher with brachytherapy than with external beam radiation therapy ${ }^{[61]}$. Preoperative intraarterial chemotherapy is another option and has been shown to have no effect on free flap results ${ }^{[62]}$.

\section{OUTCOMES AND RECURRENCE}

Because of the prolonged surgical time and extensive periods of bed rest combined with immunosuppresive therapy following sarcoma resection, surgical treatment of these tumors is generally associated with high numbers of postoperative complications. Lopez et al. ${ }^{[2]}$ found that patients who received combined pedicled + free flaps after sarcoma resection had significantly higher wound complications rates compared to patients who received just one, although systemic complications were distributed equally between all groups.

Recurrence rates are generally high following flap reconstruction after resection of advanced, highgrade sarcomas ${ }^{[63]}$. Popov et al ${ }^{[64]}$ found a statistically significant correlation between recurrence and extracompartmental tumor location $(P<0.01)$ and large tumor size $(>4 \mathrm{~cm})(P<0.01)$. Postoperative wound complications can also lead to amputation following tumor resection and flap reconstruction.

\section{CONCLUSION}

As wide local excision has become the most commonly accepted approach to the surgical treatment of sarcomas, reconstructive surgical techniques become crucial to the success of this line of therapy. Although pedicled flaps have been traditionally preferred for oncologic resections, their use is sometimes precluded by the use of neoadjuavant radiation as well as the size of the defect left after the resection. The need to reestablish function also makes the use of a pedicle/local flap less optimal. Several recent studies have reported successful functional and aesthetic results using free tissue transfer as the main modality for reconstruction after sarcoma resection of the limb ${ }^{[6,7,56]}$. Free tissue transfer allows for the application of healthy vascularized tissue to the defect while also providing freedom of flap positioning as well as avoidance of stretching or kinking of the vasculature ${ }^{[2]}$. Studies of sarcoma resection and free tissue reconstruction have reported high success rates, with complication rates ranging between $2 \%-22 \%^{[7,64,65]}$ and limb salvage rates close to $100 \%{ }^{[6,57,64,65]}$. Flap choice is dependent on tumor and defect size, tissue type and function, as well as donor site availability, thus resulting in numerous different treatment options. Given the low incidence and prevalence of lower extremity sarcomas as well as the heterogeneity of the sarcomas and their respective neo-adjuvant treatments, there are currently no clear treatment guidelines or specific algorithms for the reconstruction of soft tissue defects following oncologic resection. The lack of significant case volume makes it difficult for any single institution to conduct a study comparing the success rates of various flaps, and although a systematic review would be helpful, the innate nature of the pathology also leads to a paucity of literature consisting largely of studies describing small numbers of isolated cases. This descriptive review however attempts to provide an overview of the various reconstructive options that are available, as well as the considerations that must be taken into account when treating patients with soft tissue defects of the lower limb following sarcoma resection.

\section{DECLARATIONS}

\section{Authors' contributions}

Performed the literature search and reviewed the articles: Azadgoli B, Perrault DP 
Drafted the manuscript: Azadgoli B

Revised the manuscript: Carre AL, Wong AK

Reviewed the manuscript and approved its final version: all authors

\section{Financial support and sponsorship}

None.

\section{Conflicts of interest}

There are no conflicts of interest.

\section{Patient consent}

Not applicable.

\section{Ethics approval}

Not applicable.

\section{Copyright}

(c) The Author(s) 2018.

\section{REFERENCES}

1. Swallow CJ, Catton CN. Local management of adult soft tissue sarcomas. Semin Oncol 2007;34:256-69.

2. Lopez JF, Hietanen KE, Kaartinen IS, Kääriainen MT, Pakarinen TK, Laitinen M, Kuokkanen H. Primary flap reconstruction of tissue defects after sarcoma surgery enables curative treatment with acceptable functional results: a 7-year review. BMC Surg 2015;15:71.

3. Nijhuis PH, Schaapved M, Otter R, Molenaar WM, van der Graaf WT, Hoekstra HJ. Epidemiological aspects of soft tissue sarcomas (STS) - consequences for the design of clinical STS trials. Eur J Cancer 1999;35:1705-10.

4. Pollock RE, Karnell LH, Winchester DP. The National Cancer Data Base report on soft tissue sarcoma. Cancer 1996;15:2247-57.

5. Abramson DL, Orgill DP, Singer S, Gibstein LA, Pribaz JJ. Single-stage, multimodality treatment of soft-tissue sarcoma of the extremity. Ann Plast Surg 1997;39:454-60.

6. Cordeiro PG, Neves RI, Hidalgo DA. The role of free tissue transfer following oncologic resection in the lower extremity. Ann Plast Surg 1994;33:9-16.

7. Serletti JM, Carras AJ, O'Keefe RJ, Rosier RN. Functional outcome after soft-tissue reconstruction for limb salvage after sarcoma surgery. Plast Reconstr Surg 1998;102:1584-5.

8. Heiner J, Rao V, Mott W. Immediate free tissue transfer for distal musculoskeletal neoplasms. Ann Plast Surg 1993;30:140-6.

9. Barner-Rasmussen I, Popov P, Bohling T, Tarkkanen M, Sampo M, Tukiainen E. Microvascular reconstruction after resection of sarcoma of the leg. Br J Surg 2009;96:482-9.

10. Leow AM, Halim AS, Wan Z. Reconstructive treatment following resection of high-grade soft-tissue sarcomas of the lower limb. J Orthop Surg (Hong Kong) 2005;13:58-63.

11. Momeni A, Kalash Z, Stark GB, Bannasch H. The use of the anterolateral thigh flap for microsurgical reconstruction of distal extremities after oncosurgical resection of soft-tissue sarcomas. J Plast Reconstr Aesthetic Surg 2011;64:643-8.

12. Rudiger HA, Ngan SY, Choong PF. Surgical outcome of soft tissue sarcomas of the adductor compartment. J Orthop Surg (Hong Kong) 2009; 17:284-7.

13. Fortner JG, Kim DK, Shiu MH. Limb-preserving vascular surgery for malignant tumors of the lower extremity. Arch Surg 1977;112:3914.

14. Muramatsu K, Ihara K, Miyoshi T, Yoshida K, Taguchi T. Clinical outcome of limb-salvage surgery after wide resection of sarcoma and femoral vessel reconstruction. Ann Vasc Surg 2011;25:1070-7.

15. Ng RW, Chan JY, Mok V. A modification of technique to cover a large posterior thigh defect using an anterolateral thigh flap. Ann Plast Surg 2008;61:201-3.

16. Zbuchea A. Lateral genicular artery flap for reconstruction of a large knee defect following oncological resection - case report. Chirurgia (Bucur) 2016;111:353-7.

17. Nahabedian MY, Mont MA, Orlando JC, Delanois RE, Hungerford DS. Operative management and outcome of complex wounds following total knee arthroplasty. Plast Reconstr Surg 1999;104:1688-97.

18. Vaienti L, Marchesi A, Palitta G, Gazzola R, Parodi PC, Leone F. Limb trauma: the use of an advanced wound care device in the treatment 
of full-thickness wounds. Strateg Trauma Limb Reconstr 2013;8:111-5.

19. Cadenelli P, Bordoni D, Radaelli S, Marchesi A. Proximally based anterolateral-thigh (ALT) flap for knee reconstruction: an advancement propeller perforator flap. Aesthetic Plast Surg 2015;39:752-6.

20. Baxter BT, Mahoney C, Johnson PJ, Selmer KM, Pipinos II, Rose J, Neff JR. Concomitant arterial and venous reconstruction with resection of lower extremity sarcomas. Ann Vasc Surg 2007;21:272-9.

21. Miyamoto S, Fujiki M, Nakatani F, Sakisaka M, Sakuraba M. Free flow-through anterolateral thigh flap for complex knee defect including the popliteal artery. Microsurgery 2015;35:458-88.

22. Lee HY, Cordeiro PG, Mehrara BJ, Singer S, Alektiar KM, Hu QY, Disa JJ. Reconstruction after soft tissue sarcoma resection in the setting of brachytherapy: a 10-year experience. Ann Plast Surg 2004;52:486-91.

23. Choudry U, Moran S, Karacor Z. Soft-tissue coverage and outcome of gustilo grade IIIB midshaft tibia fractures: a 15-year experience. Plast Reconstr Surg 2008;122:479-85.

24. Saito A, Sawaizumi M, Imai T, Matsumoto S. Reconstruction following resection of soft-tissue sarcomas at the ankle region in seven patients. J Plast Reconstr Aesthetic Surg 2010;63:1712-6.

25. Zweifel-Schlatter M, Haug M, Schaefer DJ, Wolfinger E, Ochsner P, Pierer G. Free fasciocutaneous flaps in the treatment of chronic osteomyelitis of the tibia: a retrospective study. J Reconstr Microsurg 2006;22:41-7.

26. Hong JP, Shin HW, Kim JJ, Wei F-C, Chung YK. The use of anterolateral thigh perforator flaps in chronic osteomyelitis of the lower extremity. Plast Reconstr Surg 2005;115:142-7.

27. Weichman K, Allen Jr. RJ, Thanik V, Matros E, Mehrar BJ. Adipofascial anterolateral thigh free flaps for oncologic hand and foot reconstruction. J Reconstr Microsurg 2015;31:684-7.

28. Agostini T, Agostini V. Adipofascial anterolateral thigh free flap for hemifacial atrophy. Acta Otorhinolaryngol Ital 2009;29:103-7.

29. Cribb GL, Loo SCS, Dickinson I. Limb salvage for soft-tissue sarcomas of the foot and ankle. J Bone Joint Surg Br 2010;92:424-9.

30. Brenner P, Rammelt S. Abdominal wall and foot reconstruction after extensive desmoid tumor resection with free tissue transfer. Langenbeck's Arch Surg 2002;386:592-7.

31. Medina MA, Salinas HM, Eberlin KR, Driscoll DN, Kwon JY, Austen WG Jr, Cetrulo CL Jr. Modified free radial forearm fascia flap reconstruction of lower extremity and foot wounds: optimal contour and minimal donor-site morbidity. J Reconstr Microsurg 2014;30:51522.

32. Struckmann V, Hirche C, Struckmann F, Kolios L, Lehnhardt M, Kneser U, Daigeler A. Free and pedicled flaps for reconstruction of the weightbearing sole of the foot: a comparative analysis of functional results. J Foot Ankle Surg 2014;53:727-34.

33. Zaretski A, Amir A, Meller I, Leshem D, Kollender Y, Barnea Y, Bickels J, Shpitzer T, Ad-El D, Gur E. Free fibula long bone reconstruction in orthopedic oncology: a surgical algorithm for reconstructive options. Plast Reconstr Surg 2004;113:1989-2000.

34. Capanna R, Bufalini C, Campanacci M. A new technique for reconstruction of large metadiaphyseal bone defects: a combined graft (allograft shell plus vascularized fibula). Orthop Traumatol 1993;2:159-77.

35. Beris AE, Lykissas MG, Korompilias AV, Vekris MD, Mitsionis GI, Malizos KN, Soucacos PN. Vascularized fibula transfer for lower limb reconstruction. Microsurgery 2011;31:205-11.

36. Yajima H, Tamai S. Twin-barrelled vascularized fibular grafting to the pelvis and lower extremity. Clin Orthop Relat Res 1994;(303):17884.

37. Duffy GP, Wood MB, Rock MG, Rock MG, Sim FH. Vascularized free fibular transfer combined with autografting for the management of fracture nonunions associated with radiation therapy. J Bone Jt Surg - Ser A 2000;82:544-54.

38. Ruch DS, Koman LA. The fibula-flexor hallucis longus osteomuscular flap. J Bone Jt Surgery-British Vol 1997;79:964-8.

39. Mastorakos DP, Disa JJ, Athanasian E, Boland P, Healey JH, Cordeiro PG. Soft-tissue flap coverage maximizes limb salvage after allograft bone extremity reconstruction. Plast Reconstr Surg 2002;109:1567-73.

40. Enneking WF, Dunham A, Gebhardt M, Malawar M, Pritchard DJ. A system for the functional evaluation of reconstructive procedures after surgical treatment of tumors of the musculoskeletal system. Clin Orthop 1993;(286):241-6.

41. Doi K, Ihara K, Kawai S. Limb-sparing surgery in synovial sarcoma of the forearm and lower leg by reinnervated free muscle transfer. Plast Reconstr Surg 1998;102:442-7.

42. Doi K, Kuwata N, Kawakami F, Hattori Y, Otsuka K, Ihara K. Limb-sparing surgery with reinnervated free-muscle transfer following radical excision of soft-tissue sarcoma in the extremity. Plast Reconstr Surg 1999;104:1679-87.

43. Tsukushi S, Nishida Y, Sugiura H, Nakashima H, Ishiguro N. Results of limb-salvage surgery with vascular reconstruction for soft tissue sarcoma in the lower extremity: Comparison between only arterial and arterovenous reconstruction. J Surg Oncol 2008;97:216-20.

44. Nishinari K, Krutman M, Aguiar Junior S, Pignataro BS, Yazbek G, Zottele Bomfim GA, Teivelis MP, Wolosker N. Surgical outcomes of vascular reconstruction in soft tissue sarcomas of the lower extremities. J Vasc Surg 2015;62:143-9.

45. Wortmann M, Alldinger I, Böckler D, Ulrich A, Hyhlik-Dürr A. Vascular reconstruction after retroperitoneal and lower extremity sarcoma resection. Eur J Surg Oncol 2017;43:407-15.

46. Rosenthal HG, Terek RM, Lane JM. Management of extremity soft tissue sarcomas. Clin Orthop Relat Res 1993;(289):66-72.

47. O’Sullivan B, Davis A, Turcotte R, Bell R, Wunder J, Catton C, Kandel R, Sadura A, Tu D,Pater JJ. Five-year results of a randomized phase III trial of pre-operative vs post-operative radiotherapy in extremity soft tissue sarcoma. J Clin Oncol 2004;22:151-2. 
48. Baldini EH, Lapidus MR, Wang Q, Manola J, Orgill DP, Pomahac B, Marcus KJ, Bertagnolli MM, Devlin PM, George S, Abraham J, Ferrone ML, Ready JE, Raut CP. Predictors for major wound complications following preoperative radiotherapy and surgery for softtissue sarcoma of the extremities and trunk: importance of tumor proximity to skin surface. Ann Surg Oncol 2013;20:1494-9.

49. Arbeit JM, Hilaris BS, Brennan MF. Wound complications in the multimodality treatment of extremity and superficial truncal sarcomas. J Clin Oncol 1987;5:480-8.

50. Shiu MH, Turnbull AD, Nori D, Hajdu S, Hilaris B. Control of locally advanced extremity soft tissue sarcomas by function-saving resection and brachytherapy. Cancer 1984;53:1385-92.

51. O'Sullivan B, Davis AM, Turcotte R, Bell R, Catton C, Chabot P, Wunder J, Kandel R, Goddard K, Sadura A, Pater J, Zee B. Preoperative versus postoperative radiotherapy in soft-tissue sarcoma of the limbs: a randomised trial. Lancet 2002;359:2235-41.

52. Cheng EY, Dusenbery KE, Winters MR, Thompson RC. Soft tissue sarcomas: Preoperative versus postoperative radiotherapy. $J$ Surg Oncol 1996;61:90-9.

53. Kunisada T, Ngan SY, Powell G, Choong PF. Wound complications following pre-operative radiotherapy for soft tissue sarcoma. Eur $J$ Surg Oncol 2002;28:75-9.

54. Davis AM, O’Sullivan B, Turcotte R, Bell R, Catton C, Chabot P, Wunder J, Hammond A, Benk V, Kandel R, Goddard K, Freeman C, Sadura A, Zee B, Day A, Tu D, Pater J; Canadian Sarcoma Group; NCI Canada Clinical Trial Group Randomized Trial. Late radiation morbidity following randomization to preoperative versus postoperative radiotherapy in extremity soft tissue sarcoma. Radiother Oncol 2005; $75: 48-53$.

55. Townley WA, Mah E, O’Neill AC, Wunder JS, Ferguson PC, Zhong T, Hofer SO. Reconstruction of sarcoma defects following preoperative radiation: Free tissue transfer is safe and reliable. J Plast Reconstr Aesthetic Surg 2013;66:1575-9.

56. Chao AH, Chang DW, Shuaib SW, Hanasono MM. The effect of neoadjuvant versus adjuvant irradiation on microvascular free flap reconstruction in sarcoma patients. Plast Reconstr Surg 2012;129:675-82.

57. Hidalgo DA, Carrasquillo IM. The treatment of lower extremity sarcomas with wide excision, radiotherapy, and free-flap reconstruction. Plast Reconstr Surg 1992;89:96-101.

58. Brennan MF, Hilaris B, Shiu MH, Lane J, Magill G, Friedrich C, Hajdu SI. Local recurrence in adult soft-tissue sarcoma. A randomized trial of brachytherapy. Arch Surg 1987;122:1289-93.

59. Ormsby MV, Hilaris BS, Nori D, Brennan MF. Wound complications of adjuvant radiation therapy in patients with soft-tissue sarcomas. Ann Surg 1989;210:93-9.

60. Hidalgo DA, Carrasquillo IM. The treatment of lower extremity sarcomas with wide excision, radiotherapy, and free-flap reconstruction. Plast Reconstr Surg 1992;89:96-101; discussion 102.

61. Spierer MM, Alektiar KM, Zelefsky MJ, Brennan MF, Cordiero PG. Tolerance of tissue transfers to adjuvant radiation therapy in primary soft tissue sarcoma of the extremity. Int J Radiat Oncol 2003;56:1112-6.

62. Sadrian R, Niederbichler AD, Friedman J, Vogt PM, Steinau HU, Reece G, Chang D, Robb G, Evans GR. Intraarterial chemotherapy: the effects on free-tissue transfer. Plast Reconstr Surg 2002;109:1254-8.

63. Pisters PW, Leung DH, Woodruff J, Shi W, Brennan MF. Analysis of prognostic factors in 1,041 patients with localized soft tissue sarcomas of the extremities. J Clin Oncol 1996;14:1679-89.

64. Popov P, Tukiainen E, Asko-Seljaavaara S, Huuhtanen R, Virolainen M, Virkkunen P, Blomqvist C. Soft tissue sarcomas of the lower extremity: surgical treatment and outcome. Eur J Surg Oncol 2000;26:679-85.

65. Penna V, Iblher N, Momeni A, Stark GB, Bannasch H. Free tissue transfer in reconstruction following soft tissue sarcoma resection. Microsurgery 2011;31:434-40. 